\title{
FAKTOR-FAKTOR YANG BERHUBUNGAN DENGAN KETERATURAN IBU HAMIL DALAM MENGKONSUMSI TABLET FE DI WILAYAH KERJA PUSKESMAS SULIT AIR KABUPATEN SOLOK
}

\author{
NETTY HERAWATI \\ Akademi Keperawatan YPTK Solok
}

\begin{abstract}
Pregnancy is a condition in which the fetus is conceived in the mother's body, which begins with the fertilization process. Lack of iron during pregnancy will lead to iron deficiency anemia and can cause bleeding during delivery, facilitate infection and decrease the carrying capacity of acid. The need for pregnant women for Fe increases (for the formation of placenta and red blood cells) by 200-300\%, about $300 \mathrm{mg}$ of $\mathrm{Fe}$ is transferred to the fetus so that 50-75 $\mathrm{mg}$ for the formation of placenta, $450 \mathrm{mg}$ for increasing the amount of red blood and $200 \mathrm{mg}$ disappears when The type of research in this research is descriptive analytic using cross sectional design. In this study, the independent variables are motivation, the role of health workers and family support, the dependent variable is the regularity of consuming Fe tablets. Based on the statistical test, it was obtained $p$ value $0.007<0.05$, which means that there is a significant relationship between poor motivation and irregularity in consuming $\mathrm{Fe}$ tablets in the working area of Puskesmas with difficult water. Based on statistical tests, $p$ value is 0.001 0.05, which means there is a significant relationship There is a significant difference between the role of health workers and irregularity in consuming $\mathrm{Fe}$ tablets in the working area of Puskesmas with difficulty in water. Based on statistical tests, the $p$ value is $0.000<0.05$, which means that there is a significant relationship between poor family support and irregularity in consuming Fe tablets in the region. The Work of Puskesmas is Hard to Water.
\end{abstract}

Keywords: Motivation, Role of Health Officers, Family Support \& Regular Consuming Fe Tablets

\section{A. Pendahuluan}

Tujuan pembangunan kesehatan menuju Indonesia sehat 2025 adalah meningkatkan kesadaran, kemauan, dan kemampuan hidup sehat bagi setiap orang agar peningkatan derajat kesehatan masyarakat yang setinggi-tingginya dapat terwujud, melalui terciptanya masyarakat, bangasa dan negara Indonesia yang ditandai dengan penduduknya yang hidup dengan perilaku dalam lingkungan sehat, memiliki kemampuan untuk menjangkau pelayanan kesehatan yang bermutu, secara adil dan merata serta memiliki derajat kesehatan yang setinggi-tingginya di seluruh wilayah Republik Indonesia. Untuk meningkatkan derjat kesehatan yang setingginya seorang ibu hamil perlunya perhatian khusus terutama dalam asupan gizi dari makanan yang dikonsumsi kerena ibu hamil termasuk golongan yang rentan gizi dan jika asupan gizinya tidak diperhatikan, maka akan berdampak buruk terhadap janin dan ibunya. Salah satu yang sering terjasi pada ibu hamil seperti anemi defesiensi besi yang merupakan salah satu gangguan yang paling sering terjadi selama kehamilan.

Berdasarkan data WHO prevelensi anenmi di negara berkembang sekitar 41,5\% (2017), sedangkan berdasarkan profil Kesehtan jumlah ibu dengan kematian resiko tinggi salah satu penyebabnya anemi dalam kehamilan sebanyak 28\% dan berdasarkan data yang didapatkan dari laporan Dinas Kesehatan Kabupaten Solok cakupan fe ibu hamil yang masih rendah diwilayah Kerja Puskesmas sulit Air masih 59\%. Kekurangan zat besi selama kehamilan akan mengakibatkan terjadinya anemia 
defisiensi besi dan dapat menyebabkan perdarahan selam persalinan, memudahkan terjadinya infeksi dan daya angkut zat asam juga menurun. Kebutuhan ibu hamil akan fe meningkat (untuk pembentukan plasenta dan sel darah merah) sebesar 200-300\%, sekiitar $300 \mathrm{mg} \mathrm{Fe}$ di transfer ke janin sehingga 50-75 mg untuk pembentukan plasenta, $450 \mathrm{mg}$ untuk menambah jumlah darah merah dan $200 \mathrm{mg}$ lenyap ketika melahirkan. Ibu hamil disarankan untuk mengkonsumsi makanan dan minuman yang mendukung kebuthan gizinya sejak mulai hamil, supaya dapat mencegah anemi selama kehamilan. .

\section{B. Metode Penelitian}

Jenis penelitian dalam penelitian ini adalah deskriptif analitik dengan menggunakan desain cross Sectional, yaitu penelitian dilakukan dalam waktu pengukuran / pengamatan variabel independen dan dependen dalam waktu bersamaan. Dalam penelitian ini yang menjadi variabel independen adalah motivasi, peran petugas kesehatandan dukungan keluarga, variabel dependen adalah Keteraturan mengkonsumsi tablet Fe.

\section{Hasil Penelitian dan Pembahasan \\ 1. Hasil \\ a. Karakterisitik Umur Responden}

Tabel 1

Distribusi Frekuensi Responden Berdasarkan Kelompok Umur di Wilayah Kerja Puskesmas Sulit Air Kabupaten Solok

\begin{tabular}{|c|c|c|c|}
\hline No & Kelompok Umur & $\mathbf{f}$ & $\%$ \\
\hline 1 & Dewasa Awal (21 - 30 tahun) & 25 & $32,5 \%$ \\
\hline 2 & Dewasa Tengah ( $31-45$ tahun $)$ & 52 & $67,5 \%$ \\
\hline \multicolumn{2}{|r|}{ Jumlah } & 77 & 100 \\
\hline
\end{tabular}

Berdasarkan tabel diatas diketahui bahwa lebih dari sebagian $(67,5 \%)$ responden berada pada kelompok umur dewasa tengah (31 - 45 tahun).

\section{b. Pendidikan}

Tabel 2

Distribusi Frekuensi Responden Berdasarkan Tingkat Pendidikan di Wilayah Kerja Puskesmas Sulit Air Kabupaten Solok

\begin{tabular}{|l|l|l|l|}
\hline No & Pendidikan & f & \% \\
\hline 1 & Pendidikan dasar (SD- & 39 & $50,6 \%$ \\
2 & SMP) & 31 & $40,3 \%$ \\
3 & Menengah (SMA) & 7 & $9,1 \%$ \\
& Tinggi (PT) & & \\
\hline \multicolumn{2}{|c|}{ Jumlah } & $\mathbf{7 7}$ & \\
\hline
\end{tabular}

Berdasarkan tabel diatas diketahui bahwa lenih dari sebagaian $(50,6 \%)$ responden berpendidikan dasar (SD - SMP). 
Tabel 3

Distribusi Frekuensi Responden Berdasarkan Jenis Pekerjaan di Wilayah Kerja Puskesmas Sulit Air Kabupaten Solok

\begin{tabular}{|c|c|c|c|}
\hline No & Pekerjaan & $\mathbf{f}$ & $\%$ \\
\hline 1 & IRT & 44 & $57,1 \%$ \\
\hline 2 & PNS & 6 & $7,8 \%$ \\
\hline 3 & Petani & 15 & $19,5 \%$ \\
\hline 4 & Wiraswasta & 12 & $15,6 \%$ \\
\hline \multicolumn{2}{|r|}{ Jumlah } & 77 & 100 \\
\hline
\end{tabular}

Berdasarkan tabel diatas diketahui bahwa lebih dari sebagian $(57,1 \%)$ responden bekerja sebagai ibu rumah tangga (IRT)

\section{Hasil Penelitian}

a. Hasil Univariat

Motivasi Ibu Hamil

Distribusi Frekuensi Responden Berdasarkan Motivasi Ibu Hamil di Wilayah Kerja Puskesmas Sulit Air Kabupaten Solok

\begin{tabular}{|l|l|l|l|}
\hline No & Motivasi Ibu Hamil & F & \% \\
\hline 1 & Baik & 33 & $42,9 \%$ \\
2 & Kurang baik & 44 & $57,1 \%$ \\
\hline \multicolumn{2}{|c|}{ Jumlah } & \multicolumn{1}{|c|}{$\mathbf{7 7}$} & $\mathbf{1 0 0}$ \\
\hline \multicolumn{2}{|c|}{ Berdasarkan tabel diatas diketahui bahwa lebih dari sebagian (57,1\%) }
\end{tabular}
motivasi responden kurang baik.

\section{Peran Tugas Kesehatan}

Distribusi Frekuensi Responden Berdasarkan Peran Tugas Kesehatan di Wilayah Kerja Puskesmas Sulit Air Kabupaten Solok

\begin{tabular}{|l|l|ll|ll|}
\hline No & Peran Tugas Kesehatan & f & \% & \\
\hline 1 & Baik & 40 & & $51,9 \%$ & \\
2 & Kurang baik & 37 & & $48,1 \%$ & \\
\hline \multicolumn{2}{|c|}{ Jumlah } & & $\mathbf{7 7}$ & \multicolumn{2}{|c|}{$\mathbf{1 0 0}$} \\
\hline
\end{tabular}

Berdasarkan tabel diatas diketahui bahwa lebih dari sebagian $(51,9 \%)$ peran petugas kesehatan baik.

\section{Dukungan Keluarga}

Distribusi Frekuensi Responden Berdasarkan Dukungan Keluarga di Wilayah Kerja Puskesmas Sulit Air Kabupaten Solok

\begin{tabular}{|l|l|ll|ll|}
\hline No & Dukungan Keluarga & f & \% & \\
\hline 1 & Baik & 36 & & $46,8 \%$ & \\
2 & Kurang baik & 41 & & $53,2 \%$ & \\
\hline \multicolumn{2}{|c|}{ Jumlah } & & $\mathbf{7 7}$ & \multicolumn{1}{|c|}{$\mathbf{1 0 0}$} \\
\hline
\end{tabular}

Berdasarkan tabel diatas diketahui bahwa lebih dari sebagian (53,2\%) dukungan keluarga kurang baik 
Vol. 1 No.3 Desember 2019

Ensiklopedia Education Review

http://jurnal.ensiklopediaku.org

\section{Konsumsi Tablet Fe}

Distribusi Frekuensi Responden Berdasarkan Konsumsi Tablet Fe di Wilayah Kerja Puskesmas Sulit Air Kabupaten Solok

\begin{tabular}{|c|c|c|c|}
\hline No & Konsumsi Tablet Fe & $\mathbf{f}$ & $\%$ \\
\hline 1 & Teratur & 32 & $41,6 \%$ \\
\hline 2 & Tidak Teratur & 45 & $58,4 \%$ \\
\hline \multicolumn{2}{|r|}{ Jumlah } & 77 & 100 \\
\hline
\end{tabular}

Berdasarkan tabel diatas diketahui bahwa lebih dari sebagian $(58,4 \%)$ responden tidak teratur dalam mengkonsumsi tablet $\mathrm{Fe}$.

\section{b. Hasil Bivariat}

Hubungan Motivasi Ibu Hamil dengan Keteraturan Mengkonsumsi Tablet fe

Distribusi Frekuensi Responden Berdasarkan Motivasi dengan Keteraturan

Mengkonsumsi Tablet Fe di Wilayah Kerja Puskesmas

Sulit Air Kabupaten Solok

\begin{tabular}{|l|c|c|c|c|c|c|}
\hline \multirow{3}{*}{ Motivasi } & \multicolumn{6}{|c|}{ Keteraturan Mengkonsumsi Tablet Fe } \\
\cline { 2 - 7 } & \multicolumn{2}{|c|}{ Teratur } & \multicolumn{2}{c|}{ Tidak Teratur } & \multicolumn{2}{c|}{ Total } \\
\cline { 2 - 7 } & $\mathbf{f}$ & $\mathbf{\%}$ & $\mathbf{f}$ & $\mathbf{\%}$ & $\mathbf{f}$ & \% \\
\hline Baik & 20 & $60,6 \%$ & 13 & $39,4 \%$ & 33 & $42,8 \%$ \\
\hline Kurang Baik & 12 & $27,3 \%$ & 32 & $72,7 \%$ & 44 & $57,1 \%$ \\
\hline Jumlah & $\mathbf{3 2}$ & & $\mathbf{4 5}$ & & $\mathbf{7 7}$ & $\mathbf{1 0 0}$ \\
\hline
\end{tabular}

$P=0,003$

$\mathrm{OR}=4,103$

Hasil analisis antara motivasi dengan keteraturan mengkonsumsi tablet Fe didapatkan dari 44 responden, $32(72,7 \%)$ yang motivasinya kurang baik tidak teratur dalam mengkonsumsi tablet Fe. Sedangkan dari uji statistik diperoleh $p$ value 0,003 $<0,05$ yang artinya ada hubungan yang bermakna antara motivasi kurang baik dengan ketidakteraturan dalam mengkonsumsi tablet Fe di Wilayah Kerja Puskesmas Sulit Air

Hubungan Peran Tugas Kesehatan dengan Keteraturan Mengkonsumsi Tablet fe Distribusi Frekuensi Responden Berdasarkan Peran Tugas Kesehatan dengan Keteraturan Mengkonsumsi Tablet Fe di Wilayah Kerja Puskesmas

Sulit Air Kabupaten Solok

\begin{tabular}{|c|c|c|c|c|c|c|}
\hline \multirow{2}{*}{$\begin{array}{c}\text { Peran } \\
\text { Putugas } \\
\text { Kesehatan }\end{array}$} & \multicolumn{4}{|c|}{ Keteraturan Mengkonsumsi Tablet Fe } \\
\cline { 2 - 7 } & \multicolumn{2}{|c|}{ Teratur } & \multicolumn{2}{c|}{ Tidak Teratur } & \multicolumn{2}{c|}{ Total } \\
\cline { 2 - 7 } & $\mathbf{f}$ & $\mathbf{\%}$ & $\mathbf{F}$ & $\mathbf{\%}$ & $\mathbf{f}$ & \% \\
\hline Baik & 24 & $60,0 \%$ & 16 & $40,0 \%$ & 40 & $51,9 \%$ \\
\hline Kurang Baik & 8 & $21,6 \%$ & 29 & $78,3 \%$ & 37 & $48,1 \%$ \\
\hline Jumlah & $\mathbf{3 2}$ & & $\mathbf{4 5}$ & & $\mathbf{7 7}$ & $\mathbf{1 0 0}$ \\
\hline
\end{tabular}

$$
P=0,001
$$

$\mathrm{OR}=5,438$

Hasil analisis antara peran tugas kesehatan dengan keteraturan mengkonsumsi tablet Fe didapatkan dari 37 responden, $29(78,3 \%)$, peran petugas kesehatan kurang baik, responden tidak teratur dalam mengkonsumsi tablet Fe. Sedangkan dari uji statistik diperoleh $p$ value $0,001<0,05$ yang artinya ada hubungan yang bermakna antara peran petugas kesehatan kurang baik dengan ketidakteraturan dalam mengkonsumsi tablet $\mathrm{Fe}$ di Wilayah Kerja Puskesmas Sulit Air 


\section{Hubungan Dukungan Keluarga dengan Keteraturan Mengkonsumsi Tablet fe}

Distribusi Frekuensi Responden Berdasarkan Dukungan Keluarga dengan Keteraturan Mengkonsumsi Tablet Fe di Wilayah Kerja Puskesmas

Sulit Air Kabupaten Solok

\begin{tabular}{|c|c|c|c|c|c|c|}
\hline \multirow{2}{*}{$\begin{array}{c}\text { Dukungan } \\
\text { Keluarga }\end{array}$} & \multicolumn{4}{|c|}{ Keteraturan Mengkonsumsi Tablet Fe } \\
\cline { 2 - 7 } & \multicolumn{2}{|c|}{ Teratur } & \multicolumn{2}{c|}{ Tidak Teratur } & \multicolumn{2}{c|}{ Total } \\
\cline { 2 - 7 } & $\mathbf{F}$ & $\mathbf{\%}$ & $\mathbf{f}$ & $\mathbf{\%}$ & $\mathbf{f}$ & \% \\
\hline Baik & 26 & $70,3 \%$ & 11 & $29,7 \%$ & 37 & $48,1 \%$ \\
\hline Kurang Baik & 6 & $15,0 \%$ & 34 & $85,0 \%$ & 40 & $51,9 \%$ \\
\hline Jumlah & $\mathbf{3 2}$ & & $\mathbf{4 5}$ & & $\mathbf{7 7}$ & $\mathbf{1 0 0}$ \\
\hline
\end{tabular}

$$
P=0,000
$$

$\mathrm{OR}=4,394$

Hasil analisis antara dukungan keluarga dengan keteraturan mengkonsumsi tablet $\mathrm{Fe}$ didapatkan dari 40 responden, 34 (85\%), dukungan keluarga kurang baik, responden tidak teratur dalam mengkonsumsi tablet Fe. Sedangkan dari uji statistik diperoleh $p$ value $0,000<0,05$ yang artinya ada hubungan yang bermakna antara dukungan keluarga kurang baik dengan ketidakteraturan dalam mengkonsumsi tablet $\mathrm{Fe}$ di Wilayah Kerja Puskesmas Sulit Air

\section{Pembahasan}

\section{a. Hubungan Motivasi Ibu Hamil dengan Keteraturan Mengkonsumsi Tablet fe}

Berdasarkan uji statistik diperoleh $p$ value $0,007<0,05$ yang artinya ada hubungan yang bermakna antara motivasi kurang baik dengan ketidakteraturan dalam mengkonsumsi tablet Fe di Wilayah Kerja Puskesmas Sulit Air. Keinginan ibu dalam mengkonsumsi tablet fe diukur dengan ketepatan jumlah fe yang dikonsumsi, ketepatan cara mengkonsumsi tanblet zat besi, dan frekuensi konsumsi perhari. Pemberian tablet fe merupakan salah satu upaya dalam mencegah dan menanggulangi anemia, khususnya anemia kekurangan besi. Kebutuhan zat besi meningkat selama kehamilan seiringan dengan perkembangan janin. Ibu hamil dapat memenuhi kebutuhan zat besinya yang meningkat selama kehamilan dengan meminum tablet suplement tablet zat besi.dan memastikan ibu hamil makan dengan cukup dan seimbang. Kenyataan yang ditemukan dilapangan lebih dari sebagaian $(72,7 \%)$ yang motivasinya kurang baik tidak teratur dalam mengkonsumsi tablet $\mathrm{Fe}$, hal ini dikarenakan responden ditahap awal kehamilan sering mengalami gejala anemi seperti pusing, mual dan nafsu makan berkurang dan jika ibu mengkonsumsi tablet fe membuat mereka merasakan ketidaknyamanan yang memicu rasa mual sehingga membuat responden merasa malas untuk mengkonsumsi fe.

\section{b. Hubungan Peran Tugas Kesehatan dengan Keteraturan Mengkonsumsi Tablet fe}

Berdasarkan uji statistik diperoleh $p$ value $0,001<0,05$ yang artinya ada hubungan yang bermakna antara peran petugas kesehatan kurang baik dengan ketidakteraturan dalam mengkonsumsi tablet Fe di Wilayah Kerja Puskesmas Sulit Air.Peran petugas kesehatan sangat dibutuhkan, untuk itu petugas kesehatan harus mampu memberi kondisi yang dapat mempengaruhi terhadap kesehatan seseorang, peran petugas kesehatan dalam memberikan pelayanan kesehatan pada masyarakat selain melakukan pemeriksaan kehamilan juga memberikan tablet fe pada ibu hamil. Bentuk strategi petugas kesehatan yang bisa digunakan untuk meningkatkan 
keteraturan mengkonsumsi tablet fe. Semakin baik peran petugas dalam memberikan pelayanan kesehatan pada ibu hamil dalam mengonsumsi tablet fe seperti mengadakan kelas ibu hamil dapat meningkatkan pengetahuan, sikap, dan perilaku ibu hamil dalam meningkatkan keteraturannya dalam mengkonsumsi tablet fe. Kenyataan yang ditenukan dilapangan didapatkan lebih dari sebagian $29(78,3 \%)$, peran petugas kesehatan kurang baik, responden tidak teratur dalam mengkonsumsi tablet fe, hal ini dikarenakan keterbatasan dari tenaga kesehatan untuk mencatat buku pemantauan ibu hamil, sehingga kurang terpantaunya ibu hamil dalam keteraturan ibu hamil dalam mengkonsumsi fe.

\section{c. Hubungan Dukungan Keluarga dengan Keteraturan Mengkonsumsi Tablet fe}

Berdasarkan uji statistik diperoleh $p$ value $0,000<0,05$ yang artinya ada hubungan yang bermakna antara dukungan keluarga kurang baik dengan ketidakteraturan dalam mengkonsumsi tablet Fe di Wilayah Kerja Puskesmas Sulit Air. Dukungan keluarga merupakan sikap, tindakan dan penerimaan terhadap anggota keluarga, anggota keluarga dipandang sebagai yang tidak terpisahkan dalam lingkungan keluarga, anggota keluarga memandang bahwa orang yang bersifat mendukung selalu siap memberikan pertolongan dan bantuan jika diperlukan (Damayanti,2015). Adanya dukungan keluarga terutama suami dapat mendorong ibu hamil untuk lebih bersemangat dalam menghadapi perubahan-perubahan yang terjadi selama kehamilannya termasuk menjaga kesehatan kehamilannya melalui peningkatan kunjungan pemeriksaan kehamilannya dan konsumsi tablet fe. Kepedulian keluarga (suami) dalam memperhatikan kesehatan ibu hamil khususnya memonitor konsumsi tablet fe setiap hari diharapkan dapat meningkatkan kepatuhan ibu hamil dalam mengkonsumsi fe. Kenyataan yang ditemukan dilapangan, sebagian besar (85\%), dukungan keluarga kurang baik, responden tidak teratur dalam mengkonsumsi tablet $\mathrm{Fe}$, hal ini dikarenakan masih kurangnya pengetahuan dan pemahanan keluarga tentang pentingnya mengkonsumsi tablet fe selama kehamilan, sehingga keluarga masih kurang dukungan terhadapt ibu hamil dalam mengkonsumsi tablet fe seperti kurangnya keluarga dalam mengingatkan dan memonitor ibu hamil dalam mengkonsumsi tablet fe.

\section{Penutup}

Berdasarkan hasil penelitian yang telah dilakukan terhadap 77 responden di Wilayah Kerja Puskesmas Sulit Air Kabupaten solok, didapatkan lebih dari sebagaian $(57,1 \%)$ motivasi responden kurang baik dalam mengkonsumsi tablet fe, lebih dari sebagaian $(51,9 \%)$ peran petugas kesehatan baik dan lebih, sebagaian $(53,2 \%)$ dukungan keluarga yang kurang baik dan lebih dari lebih dari sebagaian $(58,4 \%)$ responden tidak teratur dalam mengkonsumsi tablet fe. Terdapat hubungan antara motivasi ibu hamil, peran petugas dan dukungan keluarga dengan keteraturan mengkonsumsi tablet fe di wilayah Kerja Pusekesmas Sulit Air Kabupaten Kota solok. Diharapkan kepada petugas kesehatan dan keluarga untuk dapat memberikan motivasi dan dukungan kepada ibu-ibu hamil yang masih belum teratur dalam mengkonsumsi tablet fe supaya lebih teratur dalam mengkonsumsi tablet fe, karena tablet fe sangat bermanfaat bagi ibu hamil. 


\section{Daftar Pustaka}

Ani, Luh Sari. 2017. Anemi Defesiensi Besi Masa Prahamil dan Hamil, Jakarta : EGC Damayanti, Denidya. 2015. Buku Pintar Perawat Profesional Teori dan Praktek Asuhan Keperawatan Jakarta: Bumi Media.

Fathonah, S. 2016. Epidemiologi Penyakit Tidak Menular. Jakarta : PT Rineka Cipta. Herawati, Oemar. 2017. Konseling Nutrisi untuk Ibu Hamil, Bandung Indriati, 2015. Kehamilan, Kelahiran, dan Perawatan Bayi. Yogyakarta : Pertama Ilmu Kemenkes. 2015. Buku Ajar Kesehatan Ibu dan Anak. Jakarta. Gavi 2016. Program Indonesia Sehat dengan Pendekatan Kesehatan, Jakarta : Depkes.

Notoaatmojo. 2012. Metodologi Penelitian Kesehatan Jakarta : Rineka Cipta -------------. 2014. Ilmu Perilaku Kesehatan Jakarta : Rineka Cipta

Pitoyo, A. 2015. Bahan Ajar : Tetap Sehal Selama Hamil. Jakarta : Unggahan StiKes Budi Waluyo

Supriyanto, Wawan, 2015. Sehat dan Bugar saat Hamil dan Melahirkan. Yogyakarta : Leutika books.

Supriyantiningsih, 2016. Anemi dalam Kehamilan dengan Kejadian Hipertensi Gravidarum. Yogyakarta.

Sutanto Priyo H, 2010. Statistik Kesehatan. Jakarta 